\title{
Colonial Law and the Inception of a Dual Land System in Nyasa- land ${ }^{1}$
}

\author{
By Clement $\mathrm{Ng}$ 'ong'ola
}

\begin{abstract}
When Nyasaland ${ }^{2}$ was formally declared a British protectorate on 14 May 1891, one of the immediate concerns of Harry Johnston, the first Commissioner and Consul General, was to settle the land question.$^{3}$ Prior to the declaration of the protectorate, vast tracts of land controlled by the indigenous peoples had been alienated or allegedly sold to European settlers by African chiefs and headmen. Johnston took it upon himself to investigate the settler acquisitions and to validate them by issuing formal title documents which he styled sertificates of claim'. These were the origins of the private land system now existing in the country which is governed by received English land law and concepts of property.

Johnston alleged that the investigation of the land acquisitions was necessary partly because the British Crown possessed rright of pre-emption' or was ithe actual owner of the soil by purchase, concession . . . or forfeiture in a greater part of the country,${ }^{4}$ and these rights had to be protected. The reaction of colonial law to the processes by which the Crown acquired such rights over what came to be called 'Crown Lands' is one of the concerns of this paper. It is also concerned with some of the legal and procedural aspects of the creation of 'private land, the other category of land which came with colonial rule. These 'legal issues', it is felt, have not received due prominence in most of the historical reviews of Johnston's land settlement. ${ }^{5}$ The focus on the reaction of colonial law to the settlement may also contribute to contemporary debates on the limits of law as an instrument for social ordering. The school of thought which the findings of this paper may substantiate challenges the $a$ priori assumption that law is a value neutral, autonomous instrument for social ordering and implores students of law . . . to recognize the
\end{abstract}

1 This paper is based on research undertaken for a doctoral dissertation entitled Statutory Law and Agrarian Change in Malawi presented to the School of Oriental and African Studies, University of London, in September 1983.

2 The country assumed the name of Malawi on attainment of independence in July 1964.

3 F.O. (Foreign Office) $84 / 2197$, Johnston to F.O., 13 October 1892 . All citations beginning with the F.O. or C.O. (Colonial Office) mark in these notes refer to correspondence and despatches located in the Public Records Office, London.

4 F.O. 84/2197, Johnsotn to F.O., 19 November 1892.

5 For a sample of historical reviews of Johnson's land settlement see B.S. Krishnarmurthy, Land and Labour in Nyasaland: 1891-1914 Ph. D. Thesis, University of London, 1964, Ch. 3, pp. 63-130; B. Pachai, Land and Politics in Malawi, 1875-1975 (Limestone Press, Canada, 1978), pp. 30-47; and A. J. Hanna, The Beginnings of Nyasaland and North-Eastern Rhodesia 1859-95 (Oxford University Press, 1969), pp. 223-245. 
relatively minor importance of legal rules compared with social, political, or administrative factors ${ }^{6}{ }^{6}$

\section{Protectorate Treaties and the Creation of Crown Lands}

It was originally assumed that all the proprietary claims of Crown representatives in Nyasaland stemmed from various treaties and agreements concluded with African political leaders. ${ }^{7}$ More than 80 of these agreements were eventually concluded between 1885 and 1895 . For the purpose of determining the extent of Crown rights inland, the agreements can be grouped into three sets.

The first set of agreements purported to confer upon the Crown if reehold rights' or restates in fee simpler over defined pieces of land. The earliest example in this set was ra deed of cession ' by which Chief Malemia of Zomba transferred land to Consul Hawes in 1885 on which the first administrative headquarters of the protectorate was to be constructed. ${ }^{9}$ The chief agreed ito cede, transfer, assign and make over absolutely and for all time coming' a defined piece of land of about one hundred acres. In return, he received an assortment of articles including yards of calico, scarfs, looking glass and knives, the total value of which was $\mathfrak{E} 7.15$ s. Consul Hawes justified the acquisition of the apparently sizeable acreage by claiming that the value of ten acres was in any case 'practically the samer. This agreement set the pattern for other soutright' government land acquisitions which included a public landing place at Chiromo on the Shire River, ${ }^{10}$ a promontory at Cape Maclear on the Lake, ${ }^{11}$ and the upper plateau of Mulanje mountain which was intended to serve as a European health retreat. ${ }^{12}$

The first common feature of this first set of agreements was the small consideration. Since land sales were hitherto unknown, chiefs had no frame of reference for determining land values. They accepted the considereation on offer, however small. Secondly, it

6 F. G. Snyder, Law and Development in the Light of Dependency Theory', Law and Society Review, 14 (1980), p. 70; c.f. R. Seidman, 'Law and Development: the Interface Between Policy and Implementation', Journal of Modern African Studies, 13, 4 (1975), pp. 644-645; M. Galanter, 'The Modernization of Law' in M. Weiner (ed.), Modernization (New York, 1969), pp. 154-156 and D. M. Trubek and M. Galanter, 'Scholars in Self-Enstrangements. Some Reflections on the Crises in the Law and Development Studies in the United States, Wisconsin Law Review (1974), pp. 1070-1080.

7 F.O. 84/2197, Johnston to F.O., 13 October 1892, and F.O. 2/128, 4 June 1897, enclosing a Memorandum of Government rights over waste and unoccupied land in British Central Africa.

8 Some of the Treaties have been reproduced in Hertslet, The Map of Africa by Treaty, (Frank Cass and Co., 1967), pp. 11-33. Pachai, op. cit., pp. 32-33 observes that 81 treaties were concluded between 1889 and 1892 , 63 of these between August 1889 and June 1891. This count does not take into account some of the tax treaties' concluded in 1895 which also ceded land rights and sovereignty. See F.O. 2/89, Johnston to F.O., 28 August 1895 and 13 November 1895 .

9 F.O. 84/1751, Hawes to F.O., 14 January 1886.

10 F.O. 84/2021, Buchanan to F.O., 18 October 1890, enclosure 1 in No. 59.

11 Hertslet, op. cit., p. 21.

12 F.O. 403/185, Johnston to F.O., 18 October 1893, enclosure No. 2. 
was assumed without debate that the chiefs were capable of conveying, and the government of acquiring, estates in fee simple and freeholds, rights which were hitherto unknown under customary law. We will probably never know how the chiefs were apprised of the new legal interests and consensus between the parties established. It is very likely that chiefs thumbed or marked documents the purport of which they did not understand. Finally, although the government assumed freehold rights, the words of conveyance employed in the documents were ambiguous and probably ineffective for that purpose under English principles of conveyancing. Land was variously ceded rabsolutely', 'in perpetuity', 'for ever' and 'for all time coming'. This homely and crude way of conveyancing was perhaps inevitable, since Johnston and other administrators had no recourse to legal advice before the transactions were effected.

The second set of agreements were concluded between 14 August 1889 and 15 June 1891. These were proper treaties, on a standard Foreign Office form, under which African chiefs ceded sovereignty to the British Crown and promised that they would rat no time cede [their] territory to any other power or enter into any agreement treaty or arrangement with any foreign government except through and with the consent of Her Majesty's government.${ }^{13}$ Cession of sovereignty by the chiefs enabled the British to proclaim a protectorate over Nyasaland, but Johnston also suggested that the treaties conferred upon the Crown rights of pre-emption in the land held by the Africans. Johnston was never specific on what such rights imported. He created at times the impression that the Crown obtained the first option to purchase land in African occupation should it come onto the market. ${ }^{14}$ Some despatches suggested that the Crown was thereby empowered to control all 'waste and unoccupied land previously under the control of the chiefs and headmen. ${ }^{15}$ Both interpretations were not borne out by the wording of the documents. Only one of the treaties in this set is acknowledged to have attempted a transfer of land rights. ${ }^{16}$ The rest implied, and were so understood by the chiefs, that the Africans had subordinated themselves to the British Crown and preferred her protection to that of the Portuguese who were also vying for sovereignty over parts of the country.

The third set of agreements were concluded after the formal declaration of the protectorate, between July 1891 and late $1895 .{ }^{17}$ The documents in this category followed no special format. Most of them contained clauses on the cession of sovereignty and territorial rights and the right to work minerals. In return, some chiefs were promised a percentage of profits from minerals worked within the ceded territory. Some of those who consented to the payment and collection of taxes were also promised a straight

13 See, for example, F.O. 83/1942, Ag. Consul Buchanan to F.O., 9 August 1889, 2 September 1889, 3 September 1889, 30 September 1889 and 12 December 1889, and F.O. 84/2021, Ag. Consul Buchanan to F.O., 17 January 1890 and 30 August 1890.

14 F.O. 84/2197, Johnston to F.O., 13 October 1892.

15 F.O. 2/66 Johnston to F.O., despatch No. 31, 31 March 1894, Report on the first three Years' Administration of British Central Africa, section on land settlement.

16 See Pachai op. cit., pp. 32-33 and F.O. 84/2021, Ag. Consul Buchanan to F.O., 17 November 1890.

17 See note 8 above. 
subsidy or a percentage of the taxes collected within their area. In effect, most of the postprotectorate treaties resembled the earlier documents under which Africans had simply placed themselves under British protection. There were, however, certain additions and variations to the common clauses which suggested that sovereignty was in some cases ceded together with land rights. The Machinjili chiefs, for example, additionally made over the ownership of the soil.$^{18}$ Mbengwa, a Makololo chief, also ceded rall other titles whatsoever . . Always excepting the land, rights, and titles already sold.${ }^{19}$ Some Makololo and Bandawe chiefs who had already signed spre-protectorate sovereignty treaties' ceded sovereignty for the second time together with 'proprietary rights', but subject to two conditions. The first was that existing villages and plantations should not be disturbed, and the second was that they should receive a percentage of the proceeds from the sales or lease of their lands by the Crown. ${ }^{20}$

The despatch which accompanied the treaty concluded with the Machinjili chiefs shed some light on what may have transpired when the post-protectorate treaties with additional clauses on land rights were concluded. Johnston wrote that he had taken advantage of a suggestion by the chief s that they should give the whole of their country to the Queen who would make the best use of it and keep bad white men out.. ${ }^{21}$ As far as he was concerned, the chiefs had transferred their land 'willingly and gratuitously', but he nevertheless gave them a present in cloth worth about $\mathfrak{E} 15$ in value. It would appear that Johnston may have misread the people's desire for British protectorate rule as an intention to give up their lands. It would appear that no effort was made to apprise them of the difference, as Johnston saw it, between cession of sovereignty and surrendering land to the Queen for the purpose of keeping bad white men out.

The despatches accompanying the other treaties generally disclosed that conflicting intentions, statements and policies were the hall marks of Johnston's conduct in the creation of Crown land. The recurring theme of the despatches, that the transfer of African land to the Crown was necessary in order to protect the natives from aggressive Europeans, was contradicted by liberal land grants to the same Europeans when Johnston attempted to settle their land claims. ${ }^{22}$ At times Johnston was no less aggressive than the settlers in acquiring land for the Crown, especially where a particular leader was

18 F.O. 84/2114, Johnston to Salisbury, 21 July 1891.

19 Hertslet op. cit., p. 28.

20 F.O. 2/54, Johnston to F.O., 5 January 1893; F.O. 403/185, Johnston to F.O., 14 October 1893, enclosure No. 9 in 286; and F.O. 2/66, Johnston to F.O., despatch No. 27, 14 March 1894.

21 See note 18 above.

22 This is best illustrated by the settlement of Henry Brown's claimt to land in Mulanje which the African vendors denied ever alienating. It was discovered that the document tendered in support of the claim was in fact dated before Brown's arrival in the country. Realising the futility of his claim, 'Brown threw himself at the mercy of the court' and was rewarded with a grant of 15 acres in fee simple. As Johnston himself indicated, his general attitude was to 'meed a claimant half-way', even if the claim was untenable. He was also lenient in the settlement of claims for the likes John Moir and A.C. Simpson, claimants who had pioneered European settlements in the country or rendered some valuable service to Johnston's administration. See F.O. 84/2197, Johnston to F.O., 13 October 1892; F.O. 2/54, Johnston to F.O., 26 August 1893; F.O. 2/66, Johnston to F.O., 26 March 1894; and F.O. 2/88, Johnston to F.O., 30 May 1895. 
reluctant to submit to Crown protection. One of his ploys in such cases was to threaten the leader with non-recognition of his political status. This course could be followed regardless of the established stature of a particular leader. Of Mpezeni, the Ngoni leader, for example, Johnston advised the Foreign Office that he was imerely a Zulu raider and not emphatically a native of the country but of the land south of the Zambezi ${ }^{23} \mathrm{He}$ further advised that the real owners of the country' who deserved recognition were the Chewa and 'Maraviı chiefs. The Foreign Office wisely refused to accept this advice. ${ }^{24}$ Johnston had, after all, approved of other less indigenous chiefs like the Yao and the Kololo. Chiefs like Mpezeni and some of the Yao slave traders who persistently refused Crown 'protection' were eventually subdued by force. In the case of the robnoxious Yaos', notably, Mkanda, Mitochi and Chikumbu, Johnston expropriated some of their lands. ${ }^{25}$

In a letter written after his recall from the territory, Johnston finally summarised his conduct thus:

Throughout the ... protectorate I have generally acquired the waste lands for the Crown by means of concessions from native chiefs; but in many cases we have come across tracts of the country utterly uninhabited and possessing no apparant owner. To satisfy the lawyer I have usually acquired these territories by first of all recognizing the nearest chief as ruler of them and then getting him to cede them to the Crown. If only for the protection of native rulers and prevention of grabbing on the part of unscrupulous Europeans, I have been obliged in this manner to make the Queen the ostensible ruler of a greater part of British Central Af rica. . . Yet it is necessary that the ownership of these lands should be primarily vested in the Crown so that their disposal may be effectually controlled by the government ${ }^{26}$

If Johnston was not always convinced of the right of chiefs to dispose of or control most unoccupied land, and if some of the treaties were no more than a facade, drawn for the satisfaction of lawyers and his superiors at the Foreign Office, it is implausible that protection of African rulers was the overriding consideration for Crown rownership or control of unoccupied land. This was first and foremost of importance to the colonial administrators. Colonialism entailed that the Crown should assert as much control over land as possible, ' . . . because in Africa no less than in England, he who controls the land is in a good position to influence government . . . ${ }^{27}$ Nyasaland administrators were so keen to establish effective government that the total area of land claimed for the Crown increased from an estimated one-fifths to three-fifths of the country's land surface. ${ }^{28}$

23 F.O. 2/65, Johnston to F.O., despatch No. 23 and enclosures, 3 March 1893.

24 Hanna op. cit., pp. 237-238.

25 F.O. 403/185, Johnston to F.O., 18 October 1893; and F.O. 2/66, Johnston to F.O., despatches No. 10, 22 January 1894 and No. 15, 4 February 1984.

26 F.O. 2/128, Johnston to the Marquis of Salisbury, 31 January 1897.

27 Y.P. Ghai and J.P.W.B. McAuslan, Public Law and Political Change in Kenya (Oxford University Press, Nairobi, 1970), p. 25.

28 See F.O. 2/54, Johnson to F.O., 3 May 1893 and Malawi National Archives (M.N.A.) file S1/492/32, folio 11, Memorandum on Sir Harry Johnston's Land Settlement, pp. 19-22; and c.f. Hanna op. cit., pp. 235-236. 
This included all land which was not alienated to the settlers as private land. Africans continued to occupy their villages and gardens, but in eyes of the administrators, they were stenants-at-will of the Crown who could be moved at any time. Their land and all unoccupied land, whether waste or fallow, became Crown land irrespective of whether the treaties with the African chiefs so provided.

The original reaction of colonial law to the assumption by the Crown of such extensive land rights fell slightly short of open endorsement. Under prevailing constitutional theories, the authority of the Crown in a protectorate was technically limited to the management of external relations and the affairs of British subjects. The indigenous peoples were supposed to retain internal sovereignty' and to be subjected to the control of the protecting power only to the extent agreed in the treaties, conventions and other agreements. ${ }^{29}$ This theory prompted law officers in the Colonial Office to advise that except where the agreements so provided, the declaration of a protectorate did not ipso facto pass to the Crown the property in the 'soils and minerals' of the protected country, and the powers of colonial administrators to control land dispositions were not unlimited. ${ }^{30}$

By the beginning of the twentieth century, however, the realities of colonialism began to cause a shift in theory. The belief that an infusion of settlers was necessary for the development of protectorates like Nyasaland was gaining prominence. It was also believed that the settlers could be attracted to such areas by the possibility of cheap land grants, but the grants could not be promised if most land remained under the control of African chiefs. ${ }^{31}$ Legal opinions thus began to endorse the view that in protectorates over 'semibarbarous peoples', with no settled system of government, 'the right of dealing with waste and unoccupied land accrues to Her Majesty by virtue of her right to the protectorate ${ }^{32}$

This view was translated into local law by Nunan, the Chief Judicial Officer, in the cases of Cox v. The A.L.C. and Pettit v. The A.L.C:, otherwise known as the kombe cases. ${ }^{33}$ The central issue in both cases was the validity of an agreement dated 2 August 1900 by which one Chief William granted a monopoly for the collection of strophantus seeds (kombe) in his territory to the defendant, the African Lakes Corporation. Nunan held that the agreement was invalid for want of consideration. He also held that the agreement was ultra-vires Chief William. He was no longer the landlord of the land over which he was chief, the legal ownership having passed with sovereign rights to the sovereign of great Britain . . . by treaties signed by his predecessors. The most pertinent

29 H. Jenkyns, British Rule and Jurisdiction Beyond the Seas (Clarendon Press, 1902), pp. 165-166.

30 F.O: 403/198, C.O. to F.O., 19 July 1894.

31 Ghai and McAuslan loc. cit.

32 F.O. 2/693, F.O. to Law Officers, 18 November 1899; and H. Morris and J. Read, Indirect Rule and the Search for Justice (Claredon Press, 1972), pp. 48-49.

33 See F.O. 2/471, Sharpe to the Marquis of Lansdowne, despatch No. 188 and enclosures, 29 July 1901 for copies of Nunan's decision in both cases. The copies were no produced in euch a way as to enable every quotation in this paper to be supported by a specific page reference. 
of the treaties acknowledged the cession of rall sovereign rights, including all mineral and mining rights absolutely and without reserve. Nunan conceded that it was sufficiently vague, and ran English conveyancing counsel would find very much to quarrel with it. He nevertheless gave it the widest interpretation, in the interest of the British . . . and the natives themselves', and held that the chief could no longer dispose of land, easements or profits a prendre without the consent of His Majesty's Commissioner.

This ruling applied to all chiefs in the protectorate because, according to Nunan, they had practically lost their authority and influence to the Commissioner upon the establishment of colonial rule. Those who maintained their rule invariably relied on the support of the administration; without it, they were as a reed shaken by the wind. In this setting, Nunan concluded, orthodox constitutional principles on protectorate rule did not apply, and the Crown's authority to deal with the land did not stem from the treaties, which were in any case vague, but from the very fact of declaring a protectorate over the natives.

Nunan's decision was probably of benefit to the Africans in the short term. It prevented chiefs like William from recklessly ceding land and mineral rights to unscrupulous settlers. Its primary effect, however, was to preserve colonial interests. There was concern that under the orthodox constitutional theory of protectorate rule the Crown's assumption of extensive land administration powers could possibly be challenged as contrary to the protectorate treaties concluded with the African chiefs. Such a challenge was bound to lead to administrative chaos. Nunan's contention that the authority of the Crown did not stem from the treaties was intended to pre-empt such a challenge. In due course, the need for pre-empting possible challenges to the Crown's ample jurisdiction in land matters was obviated by the evolution of the common law. British courts evolved the rule that even in protectorates the Crown could exercise ample jurisdiction over African land and other matters if this was in pursuance of an Order-in-Council for the administration of justice, peace, order and good government. ${ }^{34}$ An act done in pursuance of such an Order was an 'Act of Stater which fell beyond the purview of the courts. ${ }^{35}$ Even if it appeared that the Crown was exceeding its authority as a protecting power, the courts would not intervene. As Lord Denning finally stated in a celebrated case,

'... The courts themselves will not mark out the limits [of the Crown's jurisdiction]. They will not examine the treaty or grant under which the Crown acquired jurisdiction: nor will they inquire into the usage or sufferance or other lawful means by which the Crown may have extended its jurisdiction. The courts rely on the representatives of the Crown to know the limits of jurisdiction and keep within it. Once jurisdiction is exercised by the Crown the courts will not permit it to be challenged. Thus if an order in council is made, the courts will accept its validity without question. ${ }^{36}$

34 Re Southern Rhodesia (1919) A.C. 211 and Rex v. Earl of Crewe, ex parte Sekgome (1910) 2 K.B. 526.

35 Sobhuza II v. Millar (1926) A.C. 518.

36 Nyali v. the Attorney-General (1955) 1 Q.B. 1 at p. 15. 
The pertinent Order-in-Council for Nyasaland was issued on 11 August $1902 .{ }^{37}$ It typically provided for the establishment of order and good government and the exercise of jurisdiction over all natives in the protectorate. It also vested all rights of His Majesty in relation to any Crown lands in the Commissioner as a Trustee. He was also empowered to make grants, leases and other dispositions of Crown lands on such terms and conditions as he saw fit. Article 2 of the Order defined Crown lands as sall public lands in the protectorate which are subject to the control of Her Majesty by virtue of any Treaty, Convention, or Agreement, or His Majesty's protectorate, and all lands which shall have been acquired by His Majesty for the public service or otherwise howsoever.

The problem with this definition, as this paper has so far attempted to demonstrate, was that the extent of the land conferred upon the Crown by treaties and agreements concluded with African chiefs was not very certain. The agreements which purported to transfer land to the Crown for public use were not many. The majority attempted to cede sovereignty over ill-defined territories, and where this included land holding rights, African chiefs may not have been fully apprised of the consequences. By Johnston's own admission, some of the treaties were a charade. If the Crown's assertion of proprietary rights over all land not disposed of as private land were solely to derive from such agreements, Nunan was probably right to fear that the Crown's conduct in land administration could be contested. But the implication of the evolution of the common law, as discussed above, was that this could not be permitted, especially after the publication of the 1902 Order-in-Council. Anything done by the Commissioner pursuant to this order would be an Act of State. If it was clearly contrary to a prior treaty with an African chief, the courts would still ref use to intervene, whether or not the judicial inaction was at the expense of the colonized and less dominant sector in the colonial set-up. As asserted elsewhere, 'Those brought up in the traditional view of the judiciary as being the bulwark against any danger of autocratic tendencies on the part of the executive may find all this somewhat surprising ${ }^{38}$

\section{Certificates of Claim and the Creation of a Private Land System}

The circular requesting all European settlers to submit land claims to Harry Johnston for verification was published on 18 July 1891. The investigation of the claims commenced in the early autumn of 1892 . The claims submitted were divided into two groups. The first group, Johnston alleged, consisted of well-documented, uncontroversial claims relating to mineral rights which were summarily investigated and approved. The second group consisted of claims to surface land with or without mineral rights. Where no document supported such a claim, as in the case of claims tendered by some of the missionaries, it was admissible only where lengthy occupation and much building or

37 Published in London Gazette on 15 August 1902.

38 Morris and Read, op. cit., p. 60. 
cultivation could be proved. In the majority cases, supporting documents signed by African chiefs or headmen who alienated the land were a pre-requisite. Johnston or one of his trusted assistants then proceeded to the locality to ascertain the vendor's right to dispose the land, competing claims, the boundaries of the land, sufficiency of consideration for the grant, and any rights of the Africans over villages and plantations which required protection. ${ }^{39}$ Following Colonial Office requirements, the investigation also attempted to ensure that there were no monopolies or privileges which were inconsistent with British sovereignty or the treaties made between the Crown and African chiefs or other foreign powers. ${ }^{40}$ If the quidelines set were generally satisfied, Johnston issued a certificate of claim which became irrefutable evidence of the right or interest claimed. A total of 73 certificates were issued of which 60 or so affected private land rights estimated at 3700000 acres out of a total land surface of the protectorate originally estimated at about 25161924 acres. $^{41}$

The investigation of private land claims was complete by October 1893 when Johnston submitted his second report on the subject to the Foreign Office. He reported with a considerable measure of satisfaction that the rights of European settlers and the government were now sharply defined, and the settlement was on the whole acceptable and satisfactory to the settler and indigenous communities. The Foreign Office acknowledged Johnston's extraordinary industry in the exercise and hoped that the land question had been placed on 'a just and sound basis.${ }^{42}$ Latter-day historians have now demonstrated beyond doubt that the settlement was not satisfactory for the indigenous groupings. ${ }^{43}$ It should be added that it was neither satisfactory for the settlers nor for the government, and the new land system did not generally stem from a sound basis. As in the creation of Crown lands, Johnston proceeded with the investigation of land claims without sufficient regard for consistency and legality. Important questions on customary land tenure were glossed over and the guidelines which himself set were at times ignored. This belated uncharitable assessment can be substantiated by a review of the conflicts and controversies which arose from the following standard provisions of certificates of claim for surface land rights: the preamble; boundary and survey provisions; the compulsory acquisition clause; the mining royalty clause and the non-disturbance clause.

39 For details on the procedures followed in the settlement of private land claims see $\mathrm{H}$. H. Johnston, British Central Africa (Methuen \& Co., 1897), pp. 112-113; F.O. 84/2197, Johnston to F.O., Report on the settlement of Land Claims in the Shire Province of Nyasaland, 13 October 1892; and F.O. 403/185, Johnston to F.O. despatch No. 283, enclosure 1, Report on Settlement of Land Claims in British Central Africa, 14 October 1893.

40 F.O. 403/198, C.O. to F.O., 19 February 1894.

41 MNA file S1/4111I/33, folio 31, Governor Young to Sir Cunliffe Lister, confidential despatch, 14 March 1934, pp. 9-11, para. 11; and c.f. Pachai op. cit., pp. 37-40 for discrepancies in the number of certificates issued and the area of land which they affected.

42 F.O. 403/196, C.O. to F.O., 15 October 1894.

43 See note 5 above. 


\section{The Preamble}

The first paragraph of the preamble in certificates of claim often recited that Johnston was duly authorised by Her Majesty's Government to enquire into and settle all land claims. Evidence of such an authorisation is difficult to locate. One Foreign Office memorandum suggested that not authority was issued, but Johnston derived his powers from the protectorate treaties concluded with native chiefs under which the Crown 'purchased native lands' or acquired 'rights of pre-emption'.44 The unsatisfactory nature of these treaties has already been noted. It should also be recalled that when the settlement exercise commenced in 1892, some of the important chiefs had not yet ceded sovereignty or land rights. Johnston may have overstepped his authority, if any, by entertaining claims to land in all parts of the protectorate. Some disgruntled claimants made half-hearted attempts to challenge the legitimacy of the exercise,${ }^{45}$ but the majority took Johnston's authority for granted. The settlement was eventually regarded by the settlers and the Foreign Office as a fait accompli.

The second paragraph of the preamble also controversially recited that the claimant had purchased an estate in fee simple, and that the vendor was its previous sole and rightful owner. These assertions indicated Johnston's lack of respect for, or knowledge of, customary land law. It is fairly certain now that no chief could be regarded as the sole and rightful owner' of customary land among the major ethnic groups of the country. The certificate of claim confused the English property concept of rownership with political control of a domain. It is also fairly certain that sale of land ‘ was an unknown disposition in Johnston's time, and it was obviously ridiculous to suggest or confirm that chiefs made disposition of land rights which never existed in their system of jurisprudence such as the freehold or leasehold interests. ${ }^{46}$

Johnston was not completely unaware of the fact that chiefs had no right to alienate land, but he suggested that they assumed the power with the tacit acceptance of their people. ${ }^{47}$ There is no evidence in his reports to support this claim. There was probably some support for, and the acceptance of, the alienations made to some of the early settlers like the missionaries. But most of the later alienations were probably made without the knowledge or consent, express or implicit, of the people. In some of the transactions the vendors were either putative chiefs or headmen promoted by rival claimants, or junior political leaders with no authority to alienate or allocate land to

44 F.O. 403/197, Memorandum by Sir Clement Hill on Commissioner Johnston's No. 55, Central Africa, October 14th 1895, respecting land claims in Central Africa Protectorate and British Sphere North of the Zambezi, 26 February 1894.

45 See F.O. 403/174 Messrs: S. Emmanuel and Simmons to the Marquis of Salisbury, 14 May 1892; and F.O. 403/198, Rev. H. Waller to F.O., 10 September 1894, and F.O. to Rev. Waller, 20 September 1894.

46 For a review of the aspects of customary land tenure in Malawi mentioned in this paragraph, see C.H.S. Ng'ong'ola, Statutory Law and Agrarian Change in Malawi Ph. D. Thesis, University of London, 1983, Ch. II.

47 Johnston, British Central Africa, p. 113. 
outsiders. ${ }^{48}$ New trade goods like guns, beads, cloth and scarfs which the concession seekers offered in return for land grants were a very strong inducement for surreptitious dealings between chiefs and the settlers, without the consent of the villagers.

Consideration for the land grant was the other important feature of the preamble which in some cases appeared elsewhere in the certificate of claim. Sufficiency of the consideration, as noted above, was one of the conditions for the recognition of a claim. This was difficult to establish since African chiefs had no frame of reference for land valuation and were likely to accept a price which amounted to a pittance. If the investigation revealed disagreements between vendor and purchaser, Johnston imposed arbitrary but equally low values which ranged from $3 \mathrm{~d}$ per acre for the best land in favoured districts like Blantyre, to $1 / 2 \mathrm{~d}$ per acre for the least wanted land. His reason for adopting this low valuation was that the settlers had already conferred great benefits upon the country by opening up the land. If the price tendered was deemed inadequate, the purchaser was given the option of increasing the amount, or having the land reduced to a size fairly compatible with the first payment. ${ }^{49}$ In one interesting case, however,. James Lindsay obtained two leases for a price which Johnston deemed excessive, especially since the land appeared to be of poor quality. Johnston induced the vendors to convert the leases into an estate in fee simple for an additional payment. His generosity to a settler who should have been aware of his bargain was perhaps unwarranted..$^{50}$

\section{Boundary and Survey Provisions}

The first 'condition' for the recognition of a claim in almost every certificate defined the boundaries of the estate. Johnston's aim was to be sedulously accurate ${ }^{51}$ in the definition of each property. Natural and physical features were the important land marks used in the description of the boundaries. Imaginary lines measured in yards or miles were also used to supplement the natural features. Precision was sometimes dispensed with in the quest for full and fairly accurate descriptions. Some of the clauses run into several pages of convoluted descriptions. It was generally impossible for the arbiters of land claims to be sedulously accurate in the absence of surveys and technical facilities, and especially when some of the properties covered distances of more than 40 or 50 miles. ${ }^{52}$ When surveys were eventually conducted in accordance with one of the condi-

48 See MNA S1/141 $/ 28$, folio 222, observations of the D.C., Kalonga, on the Report of the North Nyasa Native Reserves Commission, 4 February 1930; and folio 30, Governor Thomas to C.O., 29 November 1930.

49 Johnston, British Central Africa, p. 113.

50 F.O. 403/185, Johnston to F.O., 14 October 1893. For other examples of private land grants emanating from Johnston's generosity instead of proven land grants, see note 22 above.

51 See note 49.

52 Some of Scharrer's land purchases, for example ranged from 12 to 40 miles in width, and over 100 miles in lenght. See F.O. 84/2115, Buchanan to F.O., 2 February 1891. 
tions of the certificates, it was perhaps inevitable that discrepancies would be found between the claimed and actual acreages of some of the properties. ${ }^{53}$

Some of the certificates also stipulated that the holder should bear the cost of surveying the property; the plan produced therefrom, together with the written descriptions, becoming the rvalid and legal evidencer of the extent of the property. The first problem with this provision was the failure of the certificates to indicate whether the plan or descriptions was to prevail in conflict situations. It can only be presumed that the plans drawn after careful preparation were likely to carry more weight than the earlier hurried descriptions.

The second problem concerned responsibility for undertaking the surveys. The government would have preferred to use its employees, but some landholders received permission to engage private surveyors because of the shortage of of ficial personnel. This left room for abuse. Eugene Scharrer, for example, engaged a young man whose knowledge of the profession sonly extended to the use of a prismatic compass to make simple plans'. When a government officer subsequently made a test survey on one of his recongized claims, 79543 acres shown on the submitted plan were found to be only 68562 acres on the ground. Scharrer refused to comply with the request for fresh and accurate plans until the government offered to undertake the resurvey at a lower rate of charge. The relevant certificate was issued in 1892 and these errors were discovered in 1899. For seven years Scharrer failed to comply with one of the conditions for the recognition of his claim, but no remedial action could be taken because breaches of this nature were not anticipated when the certificates were drafted.

\section{The compulsory Acquisition Clause}

One of the standard provisions in certificates of claim gave Her Majesty's government the right to make roads, railroads, tramways or canals, for public use across any part of the . . . estate', so long as the amount of land required for such purposes did not exceed one-sixth of the estate, and the holder was assured of compensation for the disturbance of buildings or growing crops. The inadequacies of this provision surfaced by 1895 when plans were afoot for the construction of a railway for Nyasaland. A considerable part of its projected path passed through Scharrer's land, ${ }^{54}$ and he anticipated that his company would naturally be given the construction franchise. Johnston engaged an engineer in the employ of a rival company to conduct the preliminary surveys, but he was refused permission to work on Scharrer's land. When Johnston failed to persuade Scharrer to change his mind, he invoked the rights of the government under the above mentioned

53 See the following correspondence on the controversies surrounding Scharrer's certificate of claim: F.O. 2/89, Johnston to F.O., despatch No. 86 and enclosures, 12 July 1895; F.O. 2/306, Sharpe to F.O., despatch No. 61, 8 February 1900; F.O. 2/304, F.O. to Sharpe, despatch No. 52, 3 May 1900; and F.O. 403/198, C.O. to F.O., 15 October 1894.

54 Ibid. 
clause and issued a proclamation ${ }^{5 s}$ which attempted to appropriate all roads made by Scharrer on his land. Scharrer transferred his interests in the land to a new railway company whose chairman, Lord Stanmore, appealed directly to the Marquis of Salisbury at the Foreign Office. ${ }^{56}$ The Foreign Office advised Johnston that the administration was not entitled to make roads over private land or appropriate private roads without compensation. ${ }^{57}$

A strict reading of the compulsory acquisition clause would suggest that the Foreign Office was correct, and Johnston had misinterpreted a provision of his own making when he appropriated Scharrer's roads without compensation and without ensuring that the land so taken did not exceed onesixth of the estate. But the practical effect of Foreign Office interference in this matter was that Johnston was effectively prevented from using the clause when it would have been most useful. In fact the Foreign Office appeared to endorse Lord Stanmore's contention that the right conferred by the provision could only be exercised if the government itself intended to construct the railway or public works, but not when the work was to be delegated to a third party. This, surely, was not Johnston's intention when framing the clause, but if it was, then his lack of foresight was alarming.

\section{The Mining Royalty Clause}

This clause stipulated that ron all minerals metals and precious stones obtained from the said estate, a royalty of five per centrum (5\%) ad valorem shall be paid to Her Majesty's Governmentr. This seemingly innocuous clause was in 1904 the subject of three High Court disputes commonly known as the 'Mineral Rights cases.$^{58}$ The central issue in all three cases was whether the certificate of claim generally, and the royalty clause in particular, conferred upon the holder the right to all minerals in the land. This issue was provoked by the passage of mining regulations in 1899 which empowered the administration to control the issue of prospecting licenses for minerals in the protectorate. Some areas were excluded from the effects of the regulations and these included lands held under certificates of claim which expressly recognized the right of the holder to mines and minerals ${ }^{59}$ As far as the administration was concerned, the exemption applied to the few claims summarily investigated by Johnston which related only to mineral rights. All other claims to surface land rights for which certificates with the above cited royalty

55 F.O. 2/88, Johnston to F.O., despatch No. 72, 7 June 1895.

56 F.O. 403/299, Lord Stanmore to the Marquis of Salisbury, despatch No. 32 plus enclosures, January 1896.

57 F.O. 2/105, F.O. to Johnston, 27 May 1896.

58 Augusto Paulocci v. The Commissioner For Mines and Crown Prosecutor v. Paulocci were disposed of in a judgement passed on 2 February 1904 and reported in the British Central Africa Gazette on 20 February 1904. The third case, Crown Porosecutor v The British Central Africa Company was decided on 13 October 1904 and reported in B.C.A. Gazette for 31 October 1904.

59 S. 2(b) of the B.C.A. Mining Regulations, 1899 in F.O. 2/207, F.O. to Sharpe, despatch No. 14, 26 June 1898. 
clause were issued were not exempted. The administration therefore insisted that it should regulate prospecting and mining on all such lands. The holders of the certificates contended, on the other hand, that as holders of estates in fee simple, they were entitled to restrain the administration from empowering third parties to prospect on their lands without their consent. They also claimed the right to all minerals in the land, subject only to the payment of the five per cent royalty to the government.

Judge Nunan, the former Chief Judicial Officer, held that certificates of claim with the royalty clause did not pass to the holder the right to all minerals, metals and oils without reserve. Following common law precedents, he claimed that the right to 'mines royal (gold and silver), precious stones and diamonds was vested in the Crown irrespective of the holder's fee simple. Thus prospecting licenses for such proterties could be issued to third parties without the prior consent of the certificate holder. But consent was necessary for prospecting licenses affecting all other precious metals, base metals, minerals and oils. Nunan also referred to the earlier case of Cox v. The A.L.C. ${ }^{60}$ in which he claimed that all land in the protectorate was held imediately or immediately' of the Crown after the demise of African chiefs. If this was the case, he argued, the Crown could empower its representatives to control mineral exploitation while parting with the freehold of the land. An estate in fee simple did not imply that the holder obtained rabsolute ownership of the land a and all interests thereunder, for no such thing existed even under English law.

In so holding, Nunan rejected the assertion of the preamble in certificates of claim that estates in fee simple were purchased from African chiefs. He rhetorically asked:

What then is a certificate of claim? It cannot be a mere official recognition of a valid transfer of an estate in fee simple from a native chief or chiefs. An estate in fee simple is an entity peculiar to English law and unlikely to be evolved by Kapeni or Chinsomba or to be thought of by the Germans, Poles, Italians or Hungarians to whom most of the land held by the certificates of claim in the Shire Highlands was confirmed by the Crown. ${ }^{61}$

Nunan concluded that by submitting their claims to enquiry and settlement by Harry Johnston, the claimants should be deemed to have informally surrendered their land to the Crown in anticipation of a regrant upon such terms and conditions as the Crown deemed suitable. Estates in fee simple, therefore, originated from the Crown, and the certificate of claim was just a memorandum providing documentary evidence of the arrangement.

This 'surrender and regrant hypothesis' provided the platform for successful appeals lodged by the claimants in the East African Court of Appeal in Zanzibar, which was the appellate forum for Nyasaland cases at that time. The court of appeal dismissed the hypothesis as a fiction which could not be supported by evidence. It found as a fact that

61 Augusto Paulocci v The Commissioner For Mines, note 58 above. 
African chiefs were sufficiently civilized to be able to give a good legal title to land, and they conferred the estates in fee simple upon the European settlers, just as much as they conferred upon the Crown ggood legal titles through the protectorate treaties. Neither the Crown nor the certificates of claim were, therefore, the source of such rights. The certificates were in fact mere vouchers of titles already conferred upon the holders by the African chiefs. The government issued them, acting only as a protecting power, for the purpose of protecting the agreed interests of the European purchasers as well as the native vendors. The court further suggested that any conditions imposed in the certificates which did not stem from prior agreements between the parties could have been rejected by the holders, but they chose not to do so ras the consideration for obtaining the recognition of their titles by the protecting power and not as consideration for obtaining the real titler. ${ }^{62}$

Following the rejection of Nunan's surrender and regrant hypothesis', the court of appeal found it unnecessary to pass a decision on whether the Crown was entitled to exercise her prerogative over mines royal in Nyasaland. It simply held that if words can be taken to mean anything the mining royalty clause in the certificates of claim clearly recognized the right of the holder to all minerals, metals, and precious stones without reservation, subject only to the payment of the royalty of 5 per cent. On the exemption provision in the mining regulations of 1899 , the court said that its plain words could not support the contention that it referred only to the few claims on mineral rights but not the majority which related to surface land rights. The court concluded that the intention of the provision was to exempt from the mining regulations all land disposed of under certificates of claim which included the above mentioned royalty clause. ${ }^{63}$

Nunan was obviously displeased with the reversal of his decision by the court of appeal. He urged further appeals to the Judicial committee of the Privy Council on the ground that if lands ... [were] not held of the Crown but in virtue of grants from native chiefs, the validity of every land transfer granted by the government before the Order of Council of 1902 [would be] open to question ${ }^{64} \mathrm{He}$ also thought that the right of the Crown to impose various conditions in the certificates of claim, and the validity of the various purchases from the native chiefs would in every case be open to investigation and challenge. These concerns were not shared by Nunan's colleagues in the administration, ${ }^{65}$ nor by legal advisers to the Colonial Office. ${ }^{66}$ They felt that an appeal would probably fail because the decision of the court of appeal, notwithstanding some of its imperfections, was correct on the main issue, namely, the interpretation of the mining

62 Civil Appeals Nos. 7 and 8 of 1904, H.B.M. Court of Appeal for East Africa, in C.O. 525/11, 1 April 1905, pp. 45-46.

63 Ibid., pp. 48-50.

64 C.O. 525/7, Nunan to Commissioner Sharpe, 31 March 1905, enclosure No. 2 in despatch No. 102, Sharpe to C.O., 31 March 1905.

65 C.O. 525/7, Griffin to Sharpe, 4 April 1905, enclosure No. 1 in despatch No. 114, dated 5 April 1905.

66 C.O. 525/10, R.B. Finley and E. Carson, Law Officers, to A. Littleton, 15 August 1905; C.O. 525/11, C.A. Harris to H.B. Cox, Minute dated 26 May 1905. 
royalty clause and of the exemption provision in the mining regulations of 1899 . The legal advisers further observed that any municipal court was unlikely to entertain challenges to the conditions imposed in the certificates of claim issued under the authority of the British government as the sovereign power which assumed the right of conferring or disallowing claims to land. Colonial law, as seen earlier, was very protective of colonial administrators in such matters.

When the colonial office declined to take up Nunan's request for an appeal, the implication was that the East African Court of Appeal had finally established in law that European settlers in Nyasaland acquired estates in fee simple over private land directly from native chiefs, the certificates being a mere confirmation or regularization of the record. This was arguably an erroneous finding. As suggested earlier, the description adopted by the court of an African chief as the sole owner of the land capable of alienating it in fee simple was incompatible with customary land tenure. Nunan's weighty argument that the Africans could not have passed rights which did not exist under their system of jurisprudence was too casually dismissed by the court of appeal and the legal advisers to the Colonial Office. The certificate of claim was more than a mere confirmation of fee simples granted by African chiefs; it may have been the source of such rights, as it was of conditions like the five percent Crown royalty on mineral exploitation which was not imposed by the vendors of the land. Nunan's surrender and regrant hypothesis may have been a fiction, but it was an ingenious attempt to provide some legal explanation for the mess created by Johnston's land settlement.

The second point of law established by the East African Court of Appeal was that holders of land certificates were entitled to all minerals, metals and precious stones under the land. This was an unfortunate conclusion in the context of responsibility for mining development. It implied that apart from the receipt of the royalty, the government was not entitled to interfere with the prospecting and exploitation of minerals on private land. It was in the best interests of the country that prospecting licenses should be issued to any person with the means. This was the underlying reason behind Nunan's attempts to read Crown prerogatives into the certificates of claim. The practical effect of the court of appeal decision was to entrust prospecting in the early period of colonial rule to half-solvent companies and buccaneering individuals who pioneered land acquisitions in the protectorate. If the interpretation of the mining royalty clause by the court and the legal advisers to the Colonial Office was correct, this is further proof of Johnston's lack of foresight in the framing of certificates of claim.

\section{The Non-disturbance Clause}

One of Johnston's policy pobjectives in the settlement of European land claims, as noted earlier, was to ensure that existing African land rights were sufficiently saf eguarded. He contrived to achieve this through a condition in some certificates which generally stipulated that 'no native village or plantation existing . . . on the estater at the time of the certificate shall be disturbed without the consent in writing of Her Majesty's Commis- 
sioner ..., but when such consent shall have been given, the sites of such villages or plantations ... shall revert to the proprietor of the ... estater. Some variations of the clause also prohibited the natives from making new villages or plantations on the estate without the prior consent of the proprietor.

Of all the provisions in the certificates of claim, this so called nondisturbance clause has been most extensively reviewed in the history of land policies in Nyasaland ${ }^{67}$ Its imperfections and their consequences should now be obvious and need not be detailed here. It will suffice to repeat that most settlers did not interpret the clause as excluding African villages and plantations from their purchases. This attitude was partly borne out by the wording of some of the clauses to the effect that once the disturbance of the Africans had been approved, the vacated lands should revert to the proprietor of the estate. This also encouraged the settlers to regard the clause as offering transient protection to the Africans. The whole arrangement, as one missionary succintly observed, could be likened to the biblical incident in which the kinsmen of Elimelech were prevented by Boaz from purchasing an inheritance (of land) without the encumbrance of Ruth, the widowed daughter-in-law of the dead man, Elimelech. ${ }^{68}$

In due course, most of the settlers began to disregard the rencumbrances' on their land purchases. Africans resident in villages surrounded by estates were treated as tenants from whom labour services could be demanded in lieu of rent under the system known as Thangata. ${ }^{69}$ In 1903 Judge Nunan ruled that this practice was illegal in so far as free labour services were indiscriminately demanded from the original inhabitants of African villages, for whom the nondisturbance clause was contrived, as well as later arrivals and squatters. But the judge went on to suggest that a differential application of the nondisturbance clause was no longer practicable because of intermarriages and intermixing between the original residents and later arrivals. He therefore recommended the abrogation of the non-disturbance clause and the introduction of a new arrangement under which all Aricans would be allowed to reside on the estates if they paid a moderate rent, commutable by the provision of labour services, for pay, for a month during the rainy season. He suggested the appointment of a land commission to flesh-out the details of the proposed new arrangement. ${ }^{70}$

This recommendation was primarily intended to preserve labour supplies for European

67 Apart from the references in note 5 above, the non-disturbance clause has been extensively reviewed by the following: J. Kandawire, Thangata: Forced Labour or Reciprocal Assistance? (Research and Publications Committee of the University of Malawi, 1979); B.P. Wanda, Colonialism, Nationalism and Tradition: The Evolution and Development of the Legal System in Malawi, Ph.D. Thesis, University of London, 1979, Vol. 5; and B. Pachai, 'The issue of Thangata in the History of Nyasaland, Journal of Social Science 3 (1974), pp. 20-34.

68 See Nunan's judgement in Supervisor of Native Affairs v Blantyre and East Africa Company Limited, reported in B.C.A. Gazette for 30 April 1903, p. 4 where he quoted the Blantyre Mission Paper, Life and Work for January 1893; and Ruth Ch. 4.

69 For an extensive discussion of this phenomenon see Kandawire op. cit., pp. 10-32 and Pachia, 'The issue of Thangata in the History of Nyasaland' passim.

70 See note 68 above. 
estates ensured by the system of Thangata. This pandering to the needs of European estate agriculture has more recently been singled out as a major weakness of the judgement. It has been contended that the recommendation prejudged any attempts to settle the problem on the basis of the rights of the parties as defined by the certificate of claim, and paved the way for a further erosion of African land rights. It perpetuated the mischief which the judgement should have corrected. ${ }^{11}$

Although Nunan's judgement and recommendations were by no means perfect and purported to preserve European agricultural interests, he should not be too harshly criticized with the advantage of hindsight. It should not be forgotten the the erosion of African land rights did not begin with the judgement, but with Johnston's less than thorough investigation of land claims and inept drafting of the certificate of claim, including the non-disturbance clause. The certificate of claim, as this part of the essay has attempted to show, was not an ideal basis for defining African land rights, or the rights of the settlers and the colonial administration. Almost all the principal clauses engendered controversy and conflict between the administration and the settlers, or between the settlers and the Africans.

An ideal and equitable legal solution to all these conflicts and controversies would have entailed a re-examination of the entire land settlement, and this the courts were neither willing nor equiped to undertake. Law and the judiciary were ultimately subservient to those who wielded economic and political power. Africans did not wield such power in the formative years of colonial rule. It was therefore unrealistic to expect a legal solution to the problem of Thangata which would have preserved most of their land rights. Such a solution was in fact only contrived towards the end of colonial rule, when Africans assumed the reigns of economic and political power. ${ }^{72}$

\section{Concluding Remarks}

This paper has attempted to show how a dual land structure consisting of Crown lands and private land was created after the proclamation of a British protectorate over Nyasaland in 1891. Crown lands eventually encompassed approximately 85 per cent of the country's land surface, and private land covered the other 15 per cent. An important phenomenon in the creation of these two land categories was the subsumption of African land rights. African lands which were not acquired by European settlers were converted en masse into Crown lands. The majority of the Africans continued to occupy the lands under various customary laws, but only as tenants-at-will of the Crown. Those who found themselves resident on private land were similarly deemed to be tenants of the estate holder and subjected to Thangata labour tenancies. African chiefs were deemed to have transferred land to the Crown through various treaties agreements and concessions.

71 Wanda op. cit., p. 85.

72 See note 69 above. 
But a review of some of these documents has suggested that the Crown as a protecting power claimed more land rights than were actually granted by the chiefs and headmen. This was also the case with the creation of private land. African chiefs were deemed to have sold estates in fee simple to the settlers irrespective of the fact that these were alien conceptions.

There are several historical explanations for this subsumption and subordination of African land rights and interests to the Crown and the settlers. One of the most widely accepted explanations can be termed the revenue thesis'. It has been eloquently argued that lack of revenue and the parsimony of the British treasury compelled the protectorate administration to pursue land and labour policies which could generate much needed revenue. ${ }^{73}$ Thus, Johnston was compelled to appropriate African land for the Crown in order to provide the administration with potential income from land sales or leases to European settlers. Johnson, like most colonialists of his day, was also inwardly convinced that an infusion of settler enterprise was the key to agricultural development in the protectorate. ${ }^{74}$ Thus, notwithstanding several pronouncements to the contrary, the paramountcy of settler interests was another underlying element of his land policies. It has also been shown that the settlers capitalized on their privileged position and organized powerful pressure-groups which the protectorate administration was wary to antagonize. ${ }^{75}$ Thus, Johnston and his successors were compelled to deal favourably with the European settlers, at the expense of the Africans, in order to avoid local political conflicts.

These historical explanations should not incidentally deflect criticism away from Johnston's personal conduct in the land settlement. The controversies which emerged soon after the land settlement were such that, despite the many extraneous problems encountered in the exercise, Johnston cannot escape censure for lack of foresight and disregard for legality and consistency. Johnston's superiors at the Foreign Office can also be criticised for failing to check some of the glaring inconsistencies. But it should be noted that Foreign Office approval was of ten sought and obtained for what was already a fait accompli on the ground. Sheer distance between the protectorateand the metropolitan, coupled with Foreign Office pre-occupation with other more important dependencies, made close supervision of the land settlement in Nyasaland impossible. The metropolitan country also explicitly or tacitly encouraged local land arrangements which were likely to generate local revenue. It further encouraged Crown assumption of control over African land as a way of strengthening the hand of the government. Finally, the metropolitan country also believed that European settlers were crucial for the development of the protectorate.

73 Khrishnamurthy, passim.

74 R. Palmer, Johnston and Jameson: A Comparative Study in the imposition of Colonial Ruler in B. Pachal (ed.), The Early History of Malawi (Longman, 1972), p. 312.

75 S. Myambo, The Shire Highlands Plantations: a Socio-Economic History of the Plantation System of Production in Malawi, 1891-1938 M.A. Thesis, University of Malawi, 1973. 
The subsumption of African land rights was easily tolerable in this political economy. Law was in fact evolved to pre-empt any legal challenges which the Africans themselves might have contemplated. It covered and protected arbitrary and autocratic tendencies of the omnipotent colonial administrators instead of assisting in the preservation of the rights of the weaker and less dominant sector of the society. This was an inauspicious introduction of the 'Rule of Law' to the protectorate. ${ }^{76}$ 


\section{ABSTRACTS}

\section{The Durand Agreement in the Light of Certain Recent International Conventions}

\section{By Ijaz Hussain}

Pakistan's frontier with Afghanistan in the north-west known as the Durand Line came about as a result of the Durand Agreement concluded in 1893 between the British Indian and Afghan Governments. Since 1947 when Pakistan emerged as an independent State, Afghanistan has on a number of grounds challenged the validity of the Durand Agreement and hence the resulting boundary line. This question is studied in the light of two conventions, namely the 1969 Vienna Convention and the 1978 Convention on State Succession because they more or less cover all the grounds which are invoked by Afghanistan in favour of its claim. Articles 50; 52; 53 and 62 of the former convention dealing with arguments of corruption, coercion, jus cogens, and rebus sic stantibus respectively and articles 11 and 24 of the latter convention concerning boundary regimes and subsequent conduct respectively are treated at length in order to evaluate the Afghan contention on the Durand Agreement. This analysis shows that they do not support the Afghan contention in the matter.

\section{Colonial Law and the Inception of a Dual Land System in Nyasaland}

\section{By Clement $N g^{\prime}$ ong'ola}

This paper re-examines Barry Johnston's important land settlement in colonial Malawi with the aim of exploring how colonial law and legal institutions reacted to the conflicts and controversies which it engendered. This exercise should provide fresh insights into how Johnston personally conducted the settlement, and by focussing on "legal issues", add the missing element to existing historiographical accounts. The exercise should also yield information to support the view in contemporary debates on law and development that as compared to social, political and administrative factors, legal rules may have a relatively minor role to play in the ordering of society. 